\title{
Kajian Kualitas Air Sungai Condong yang terkena Buangan Limbah Cair Industri Batik Trusmi Cirebon Pipin Supenah ${ }^{1)}$, Endang Widyastuti ${ }^{2)}$ dan Rawuh Edy Priyono ${ }^{2)}$ \\ ${ }^{1)}$ Mahasiswa Program Magister IImu Lingkungan, Unsoed, Purwokerto \\ ${ }^{2)}$ Dosen Program Studi IImu Lingkungan Program Pasca Sarjana, Unsoed, Purwokerto \\ ${ }^{2)}$ Dosen Program Studi IImu Lingkungan Program Pasca Sarjana, Unsoed, Purwokerto Email: pipin supenah@yahoo.co.id
}

\begin{abstract}
The aims of this study were to assess the water quality of the River Condong and Condong River Quality Statebased on physical, chemical and biological parameters. Sampling was carried out in seven stations with 3 repetitions at intervals of one month. Water quality were analyzed descriptively by reference raw Water Quality Standard. Determination of the stateof water quality using methods Storet. Results of laboratory tests showed that the water quality of the River Condong exceed the Water Quality Standard Group II based on Government Regulation No. 82 of 2001 and in particular textile waste quality standard TSS, DO, BOD,$C O D$, $\mathrm{NH}_{3}$, sulfide, $\mathrm{Cr}(\mathrm{VI})$, phenols, oils and fats, Biological parameters using makrobentos diversity index $\left(\mathrm{H}^{\prime}\right)$ obtained a low value that is from 0 to 1.7077. Quality state based Storet method, the value of $>-31$. It can be concluded that the condition of physical, chemical and biological parameters, Condong River water showed waters not appropriate the Quality Standard for agricultural irrigation, freshwater fish breeding and infrastructure or water recreation facilities before and after the discharge of liquid waste of batik. Condong River quality state before and after the liquid waste of batik is heavily polluted.
\end{abstract}

Keywords: Condong River quality, industrial wastewater batik, Batik Trusmi

\section{Abstrak}

Penelitian ini bertujuan untuk mengkaji kualitas air Sungai Condong dan Status Mutu Sungai Condong berdasarkan parameter fisik, kimia dan biologi. Pengambilan sampel dilakukan di tujuh stasiun dengan 3 kali ulangan dalam interval waktu satu bulan. Kualitas air dianalisis secara deskriptif berdasarkan acuan Baku Mutu Air. Penentuan status mutu air menggunakan metode Storet. Hasil uji laboratorium menunjukkan bahwa kualitas air Sungai Condong melebihi Baku Mutu Air Kelas II berdasarkan Peraturan Pemerintah Nomor 82 Tahun 2001 dan baku mutu limbah textile khususnya TSS, $\mathrm{DO}, \mathrm{BOD}_{5}, \mathrm{COD}, \mathrm{NH}_{3}$, sulfida, $\mathrm{Cr}(\mathrm{VI})$, fenol, minyak dan lemak. Parameter biologi menggunakan indeks keanekaragaman makrobentos $\left(\mathrm{H}^{\prime}\right)$ didapatkan nilai yang rendah yaitu 0- 1,7077. Status mutu berdasarkan metode Storet, diperoleh nilai > -31. Hasil penelitian dapat disimpulkan bahwa kondisi kualitas fisik, kimia dan biologi air Sungai Condong menunjukkan perairan yang tidak memenuhi Baku Mutu untuk irigasi pertanian, pembudidayaan ikan air tawar dan prasarana/sarana rekreasi air sebelum maupun setelah buangan limbah cair batik. Status mutu Sungai Condong sebelum dan setelah limbah cair batik berada pada status tercemar berat.

Kata kunci: kualitas air Sungai Condong, limbah cair industri batik, batik Trusmi

\section{Pendahuluan}

Salah satu penghasil batik di Jawa Barat adalah Cirebon dan sentra pembuatan batik berada di desa Trusmi Wetan dan desa Trusmi Kulon, Kecamatan Plered, Kabupaten Cirebon disebut juga Batik Trusmi. Proses pembuatan batik identik dengan proses pembuatan motif dan pewarnaan kain. Pewarna yang umum digunakan pengrajin batik adalah pewarna sintetik karena mudah didapat juga menghasilkan warna-warna yang lebih cerah. Menurut Casta dan Taruna (2007), batik Trusmi mengenal tiga jenis warna yaitu Indigosol, Naphtol dan Indanthrene. Penggunaan pewarna sintetik dan proses pembuatan batik seperti pelepasan malam (lilin), pencucian, perandaman, dan pembilasan akan menghasilkan limbah cair yang mengandung minyak dan zat pewarna. Ramesh et al. (2007), menyatakan bahwa proses produksi tekstil/batik selain 
memerlukan air dalam jumlah yang besar, juga menghasilkan limbah yang kaya zat warna, mengandung residu pewarna reaktif dan bahan kimia, dan membutuhkan pengelolaan yang tepat sebelum dilepaskan ke lingkungan. Penghilangan kanji merupakan salah satu proses yang menyebabkan BOD tinggi dibandingkan dengan proses lainya.

Pemasakan dan maserasi kapas serta pemucatan kain akan menghasilkan asam, basa, COD, BOD, padatan tersuspensi dan zat-zat kimia (Astirin danWinarno, 2000). Menurut Toroz (2007), limbah cair textil/batik dapat menurunkan kualitas lingkungan, karena padatan tersuspensi, BOD, COD yang dihasilkan cukup tinggi melebihi batas ambang, oleh karena itu seharusnya dilakukan pengolahan limbah sebelum dibuang ke perairan. Industri Batik Trusmi Kabupaten Cirebon sebagian besar belum memiliki instalasi pengolahan air limbah, limbah cair batik dibuang ke selokan dan anak sungai yang akan bermuara pada Sungai Condong.

Sungai Condong berada di Kabupaten Cirebon yang berhulu di Kabupaten Kuningan dan bermuara di Desa Jatimerta Kebupaten Cirebon. Sungai Condong memiliki panjang 8,44 km dengan lima anak sungai yang melintasi beberapa desa diantaranya Trusmi Wetan dan desa Trusmi Kulon, Kecamatan Plered Kabupaten Cirebon (Dinas PSDAP 2014). Sungai Condong melewati pemukiman penduduk, dimanfaatkan oleh masyarakat setempat sebagai sumber irigasi pertanian dan keperluan industri seperti batik Trusmi sebagai tempat pembuangan limbah.

Pembuangan limbah cair industri Batik Trusmi tanpa pengolahan ke sungai diindikasikan sebagai penyebab perubahan kualitas air Sungai Condong. Perubahan kualitas air sungai dapat diukur dengan adanya perubahan sifat fisik, kimia, dan biologi berdasarkan baku mutu limbah batik. Status mutu air dapat digunakan sebagai dasar pengelolaan suatu perairan. Berdasarkan Keputusan Menteri Negara Lingkungan Hidup nomor 115 tahun 2003, penentuan Status Mutu Air dapat menggunakan metode Storet. Berdasarkan uraian di atas, maka perlu dikaji kualitas air Sungai Condong yang menerima buangan limbah cair industri Batik Trusmi dan status mutu Sungai Condong berdasarkan parameter fisik, kimia dan biologi.

\section{Materi dan Metode}

Penelitian dilakukan dengan metode survai. Penentuan stasiun pengambilan sampel air Sungai Condong dilakukan dengan cara Purposive Sampling pada 7 stasiun pengambilan sampel (Gambar 1). Stasiun 1 terletak pada daerah sebelum buangan limbah cair batik masuk. Stasiun 2 terletak pada masuknya buangan limbah cair batik dari sentra Batik Trusmi dengan jarak $1.000 \mathrm{~m}$ dari Stasiun 1.Stasiun 3 terletak pada lokasi $600 \mathrm{~m}$ dari Stasiun 2 dan terdapat industri batik di Desa Kalitengah. Sedangkan Stasiun 4, 5, 6 dan 7 lokasi sesudah terkena limbah batik. Pengambilan sampel dilakukan sebanyak 3 kali ulangan dengan interval waktu 30 hari. Parameter yang diukur didasarkan pada Baku Mutu Air kelas II untuk irigasi pertanian, pembudidayaan ikan air tawar dan prasarana/sarana rekreasi air menurut Peraturan Pemerintah Nomor 82 tahun 2001 yang dibatasi pada parameter untuk limbah textil (Keputusan Menteri Negara Lingkungan Hidup Nomor 51 tahun 1995) yaitu TSS, $\mathrm{pH}, \mathrm{BOD}_{5}, \mathrm{COD}, \mathrm{NH}_{3}$, krom total, sulfida, minyak/lemak, dan fenol. Parameter biologi menggunakan indeks keanekaragaman Shannon-Wiener (Odum, 1993), yaitu:

$$
H^{\prime}=-\sum(n i / N) \ln (n i / N)
$$

Keterangan : $\mathrm{H}^{\prime}$ = Indeks Keanekaragaman; $\mathrm{ni}=$ jumlah individu ke-i; $\mathrm{N}=$ Jumlah total individu dari semua spesies

Kriteria mutu nilai H' menggunakan kriteria dari Wilhm \& Dorris dalam Dahuri et al.,(1995) (Tabel 1) 
Tabel 1. Kriteria mutu nilai H' (Wilhm \& Dorris dalam Dahuri et al.,1995)

\begin{tabular}{ll}
\hline $\begin{array}{l}\text { Indeks Keanekaragaman } \\
\text { Shannon-Wiener }\end{array}$ & Mutu Lingkungan Perairan \\
\hline$>3$ & Tidak tercemar \\
$1-3$ & Tercemar sedang \\
$<1$ & Tercemar berat \\
\hline
\end{tabular}

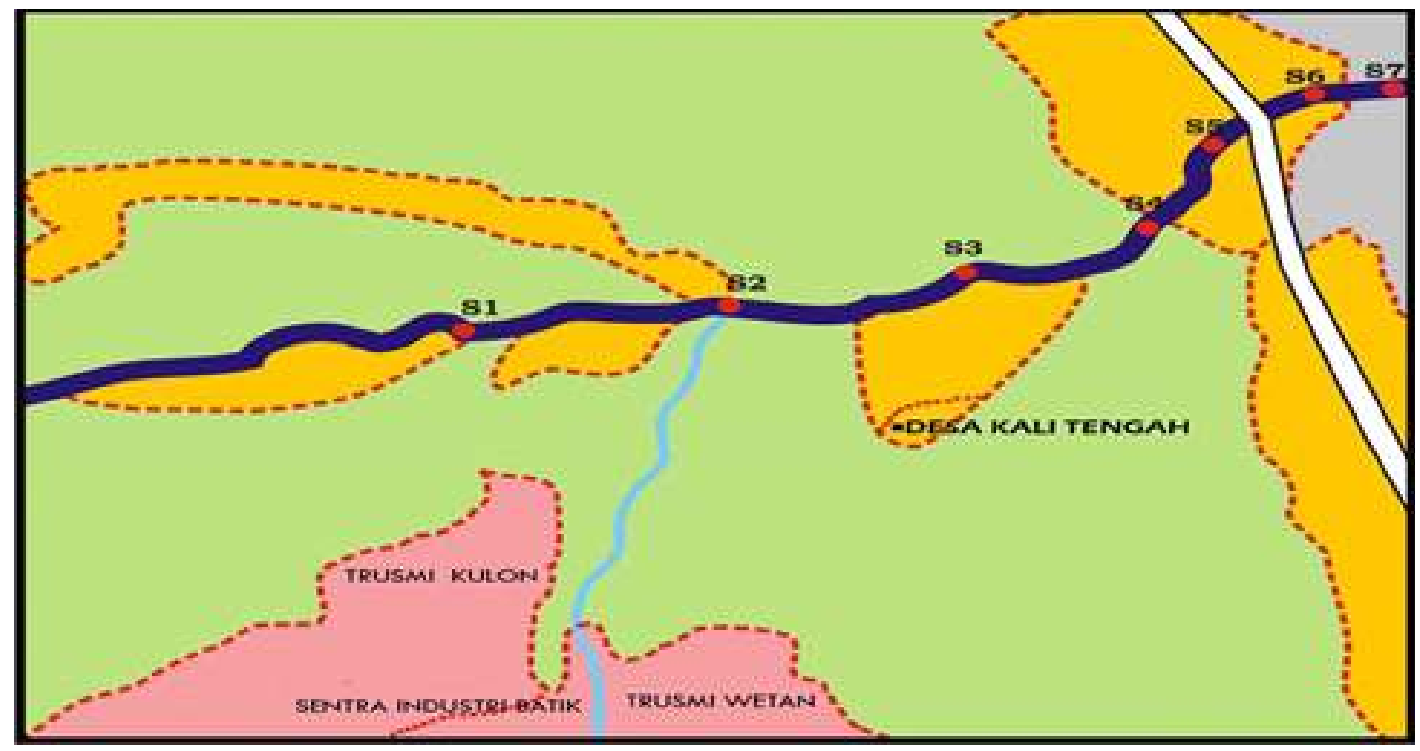

Gambar 1. Skema lokasi sampling

Keterangan :
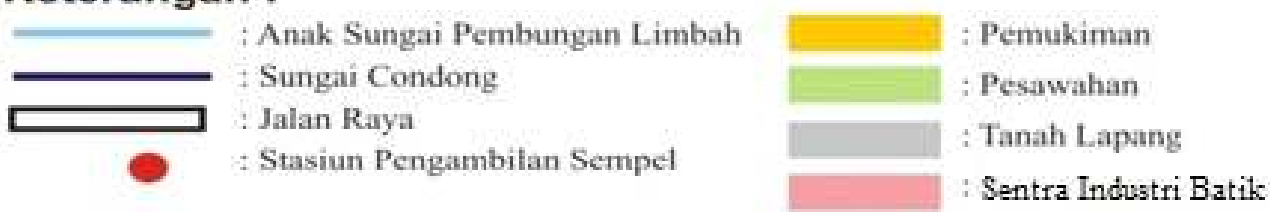

Hasil pengukuran parameter fisik, kimia dan makrobentos, dianalisa kemudian digunakan untuk penentuan status mutu berdasarkan metode Storet (Kepmen LH No.

115 tahun 2003) dan selanjutnya dilakukan penilaian status menggunakan sistem dari US-EPA (Environmental Protection Agency) (Tabel 2).

Tabel 2. Klasifikasi mutu air menggunakan sistem dari US-EPA

\begin{tabular}{lll}
\hline Kelas & Skor & \multicolumn{1}{c}{ Status Mutu } \\
\hline Kelas A : Baik Sekali & 0 & Memenuhi baku mutu \\
Kelas B : Baik & $-1 \mathrm{~s} / \mathrm{d}-10$ & Tercemar ringan \\
Kelas C : Sedang & $-11 \mathrm{~s} / \mathrm{d}-30$ & Tercemar sedang \\
Kelas D : Buruk & $>-31$ & Tercemar berat \\
\hline
\end{tabular}

\section{Hasil dan Pembahasan}

Kualitas Air Sungai Condong

Hasil pengukuran parameter fisik kimia disajikan dalam Tabel 3. 
Tabel 3. Hasil Pengukuran parameter fisik kimia Air Sungai Condong

\begin{tabular}{|c|c|c|c|c|c|c|c|c|c|c|}
\hline \multirow[t]{2}{*}{ No } & \multirow{2}{*}{ Parameter } & \multirow{2}{*}{ Satuan } & \multirow{2}{*}{$\begin{array}{l}\text { BML } \\
\mathrm{Kls} \|\end{array}$} & \multicolumn{7}{|c|}{ Rerata hasil pengukuran di stasiun } \\
\hline & & & & 1 & 2 & 3 & 4 & 5 & 6 & 7 \\
\hline & Fisika & & & & & & & & & \\
\hline 1 & Suhu & ${ }^{\circ} \mathrm{C}$ & deviasi 3 & $30 \pm 1,00$ & $30,33 \pm 1,53$ & $29 \pm 1,73$ & $28,33 \pm 1,53$ & $27,67 \pm 0,58$ & $27,33 \pm 0,58$ & $27,33 \pm 0,58$ \\
\hline 2 & TSS & $\mathrm{mgl}$ & 50 & $87,93 \pm 119,59$ & $50,20 \pm 17,84$ & $38,20 \pm 17,52$ & $54,37 \pm 33,09$ & $34,70 \pm 17,93$ & $61,27 \pm 49,03$ & $66,60 \pm 56,02$ \\
\hline 3 & $\begin{array}{c}\text { Wama } \\
\text { Kimia }\end{array}$ & TCU & $15^{\circ}$ & $11,88 \pm 1,66$ & $50,22 \pm 2,03$ & $9,46 \pm 2,69$ & $12,22 \pm 2,11$ & $10,34 \pm 3,11$ & $9,22 \pm 0,80$ & $8,30 \pm 1,25$ \\
\hline 1 & $\mathrm{pH}$ & - & 69 & $7,97 \pm 0,37$ & $7,79 \pm 0,13$ & $7,66 \pm 0,25$ & $7,62 \pm 0,34$ & $7,32 \pm 0,25$ & $7,10 \pm 0,56$ & $7,40 \pm 0,52$ \\
\hline 2 & DO & $\mathrm{mgl}$ & $>4$ & $4,93 \pm 0,58$ & $4,07 \pm 1,70$ & $5,03 \pm 1,59$ & $2,67 \pm 1,91$ & $1,93 \pm 1,23$ & $3,10 \pm 0,90$ & $2,20 \pm 0,46$ \\
\hline 3 & $B O D_{s}$ & $\mathrm{mgl}$ & 3 & $10,93 \pm 6,70$ & $11,69 \pm 7,80$ & $36,35 \pm 12,08$ & $20,56 \pm 13,39$ & $15,67 \pm 14,15$ & $28,03 \pm 19,52$ & $37,17 \pm 24,22$ \\
\hline 4 & $\mathrm{COO}$ & mgl & 25 & $89,33 \pm 68,86$ & $178 \pm 197,45$ & $1886,67 \pm 1346,45$ & $284 \pm 211,40$ & $184 \pm 96,99$ & $205,33 \pm 135,37$ & $320 \pm 192,87$ \\
\hline 5 & NH3 & mgit & Negatif & $0,69 \pm 0,27$ & $0,62 \pm 0,13$ & $0,64 \pm 0,13$ & $0,88 \pm 0,67$ & $0,58 \pm 0,03$ & $0,61 \pm 0,07$ & $1,08 \pm 0,78$ \\
\hline 6 & Sulfida & mgl & 0,002 & $0,57 \pm 0,01$ & $0,66 \pm 0,14$ & $0,62 \pm 0,14$ & $0,65 \pm 0,08$ & $0,62 \pm 0,07$ & $0,43 \pm 0,18$ & $0,54 \pm 0,15$ \\
\hline 7 & $\mathrm{Cr}_{\mathrm{r}}(\mathrm{VI})$ & $\mathrm{mgl}$ & 0,05 & $0,12 \pm 0,02$ & $0,10 \pm 0,01$ & $0,15 \pm 0,02$ & $0,11 \pm 0,02$ & $0,10 \pm 0,01$ & $0,16 \pm 0,04$ & $0,14 \pm 0,04$ \\
\hline 8 & Phend & $\mathrm{mglt}$ & 0,001 & $0,52 \pm 0,11$ & $0,43 \pm 0,17$ & $0,41 \pm 0,13$ & $0,4 \pm 0,14$ & $0,47 \pm 0,05$ & $0,46 \pm 0,11$ & $0,53 \pm 0,11$ \\
\hline 9 & $\begin{array}{l}\text { Minyak } \\
\text { Lemak }\end{array}$ & $\mathrm{mgl}$ & 1 & $14,17 \pm 6,83$ & $9,50 \pm 3,12$ & $13,00 \pm 7,37$ & $14,67 \pm 7,02$ & $8,67 \pm 5,03$ & $11,67 \pm 8,08$ & $8,50 \pm 6,76$ \\
\hline
\end{tabular}

Keterangan:

BML KLS $\|=$ Baku Mutu Air Kelas $\|$

* = Persyaratan warna perairan menurut Permenkes RI No 416 Tahun 1990

Hasil pengukuran suhu air Sungai Condong didapatkan relatif tidak berbeda berkisar $27,33-30,33^{\circ} \mathrm{C}$. Relatif kecilnya perbedaan suhu antar stasiun sebelum dan sesudah terkena limbah cair batik, dapat ditafsirkan bahwa buangan limbah cair industri Batik Trusmi tidak potensial merubah suhu perairan Sungai Condong. Suhu normal air di alam daerah tropis berkisar $20^{\circ} \mathrm{C}-30^{\circ} \mathrm{C}$ untuk kehidupan hewan air dan organisme air lainya (Suripin, 2004). Dengan demikian kondisi suhu saat penelitian tidak mengganggu kehidupan hewan dan organisme lainnya.

Nilai TSS Stasiun 2 dan Stasiun 3 didapatkan rendah, berarti limbah cair batik tidak berpotensi terhadap kenaikan nilai TSS. Kadar TSS yang dipersyaratkan Baku Mutu Lingkungan Kelas II adalah 50 mg/l. Nilai TSS diatas Baku Mutu Lingkungan pada Stasiun 1, Stasiun 6 dan 7 ditandai dengan standar deviasi yang tinggi.

Hasil pengukuran parameter warna dengan satuan TCU (True Colour Unit) berkisar 8,30-12,22 TCU, memenuhi standar Baku Mutu Lingkungan yang dianjurkan yaitu 15 TCU berdasarkan Permenkes RI No. 416 tahun 1990 tingkat warna untuk air bersih. Walaupun Stasiun 2 dan Stasiun 3 yang merupakan stasiun masuknya buangan limbah cair batik memenuhi Baku Mutu Lingkungan, hal ini perlu diantipasi karena zat warna yang terkandung dalam limbah cair batik bersifat toksik. Limbah dengan pewarna sintetis batik akan mencemari sumber-sumber air warga, baik yang dibuang ke sungai, atau yang dibuang ke tanah karena dapat meresap kedalam sumur. Dampak pencemaran baru terasa setelah beberapa puluh tahun kemudian, terutama bagi kesehatan warga, yakni ancaman kanker atau gangguan pencernaan akibat akumulasi zat-zat berbahaya yang masuk ke dalam tubuh melalui air minum (Anonim, 2010).

Hasil pengukuran parameter bau menunjukkan bahwa dari Stasiun 1 sampai Stasiun 7 berbau. Darmono (2001), mengemukakan bahwa bau air dapat disebabkan oleh beberapa faktor seperti mikroorganisme akuatik perairan, effluent rumah tangga maupun industri. Bau di Sungai Condong disebabkan buangan limbah cair batik, limbah domestik, limbah pertanian maupun limbah industri lainnya, karena Sungai Condong selain menerima limbah cair batik juga melewati pemukiman, daerah pertanian dan industri.

Nilai $\mathrm{pH}$ berkisar 7,10-7,97 dan $\mathrm{pH}$ antar stasiun relatif sama dengan selisih perbedaan yang tidak besar. Nilai $\mathrm{pH}$ di Sungai Condong dipengaruhi buangan bahan organik baik dari limbah batik, limbah domestik maupun limbah yang disebabkan oleh aktifitas pertanian 
disekitar Sungai Condong.Ali (2013), menyatakan nilai $\mathrm{pH}$ disebabkan oleh buangan limbah anorganik dan organik ke sungai. Kisaran $\mathrm{pH}$ yang diperbolehkan untuk Baku Mutu air kelas II adalah 6-9 (P.P. No 82 tahun 2001), sehingga Sungai Condong masih layak digunakan sesuai dengan peruntukannya.

Berdasarkan PP. No. 82 Tahun 2001, kadar DO yang dipersyaratkan minimum 4 $\mathrm{mg} / \mathrm{l}$ air. Hasil pengukuran DO pada Stasiun 2 dan Stasiun 3 yang merupakan stasiun masuknya limbah cair batik masih memenuhi persyaratan Baku Mutu Air Kelas II, dapat ditafsirkan bahwa buangan limbah cair industri Batik Trusmi tidak memiliki pengaruh yang nyata terhadap perubahan kandungan oksigen terlarut perairan Sungai Condong. Rendahnya kadar DO pada Stasiun 4, 5, 6 dan 7 mengindikasikan terjadinya dominasi pencemaran oleh bahan-bahan organik terutama oleh limbah domestik dari kegiatan pemukiman. Menurut Effendi (2003), DO dalam perairan dipengaruhi oleh proses dekomposisi bahan organik dan oksidasi bahan anorganik.

Kenaikan kadar $\mathrm{BOD}_{5}$ yang signifikan terjadi pada Stasiun 3 karena adanya pengrajin batik di Desa Kalitengah yang membuang limbahnya ke Sungai Condong. Pada stasiun selanjutnya setelah pembuangan limbah cair batik kadar $\mathrm{BOD}_{5}$ tinggi karena adanya aktifitas pembuangan limbah domestik rumah tangga, limbah pasar dan pertanian menyebabkan meningkatnya bahan organik dalam perairan. $\mathrm{BOD}_{5}$ Sungai Condong tidak memenuhi Baku Mutu Air Kelas II.

Hasil pengukuran kadar COD Sungai Condong pada seluruh stasiun pengamatan tidak memenuhi Baku Muku Kualitas Air Kelas II yang diijinkan berdasarkan Peraturan Pemerintah No. 82 tahun 2001 yaitu sebesar $25 \mathrm{mg} / \mathrm{l}$. Tingginya kadar COD sejalan dengan tingginya kadar BOD yang tidak memenuhi persyaratan Baku Mutu air kelas II. Banyaknya bahan organik yang sulit terdekomposisi seperti zat warna batik menyebabkan tingginya kadar COD pada Stasiun 3 yang merupakan daerah buangan limbah cair industri batik desa Kali Tengah. Desa Kali Tengah merupakan daerah industri batik juga selain sentra industri batik di Desa Trusmi Wetan dan Trusmi Kulon. Adanya bahan organik yang teroksidasi secara kimia menyebabkan jumlah oksigen yang diperlukan semakin besar.

Hasil pengukuran kadar Amoniak sebagai $\mathrm{N}$ pada seluruh stasiun pengamatan tidak memenuhi Baku Mutu Kualitas Air Kelas II, yang diijinkan berdasarkan Peraturan Pemerintah No. 82 tahun 2001 yaitu tidak diijinkan terdapat kandungan Amoniak pada perairan. Kadar amoniak juga tinggi pada stasiun sebelum dan sesudah terkena limbah batik, hal ini menggambarkan aktifitas limbah batik tidak memiliki pengaruh yang kuat terhadap amoniak dibandingkan aktifitas domestik dan pertanian. Kadar Amoniak bebas yang tidak terionisasi $\left(\mathrm{NH}_{3}\right)$ pada air tawar sebaiknya tidak lebih dari 0,02 mg/l. Kadar ammonia bebas lebih dari 0,02 $\mathrm{mg} / \mathrm{l}$, perairan bersifat toksik bagi beberapa jenis ikan (Sawyer dan McCarty, 1978).

Konsentrasi sulfida yang diperoleh berkisar 0,43-0,66 mg/l dan tertinggi pada Stasiun 2. Peningkatan konsentrasi sulfida pada perairan disebabkan adanya pembuangan zat warna batik pada proses pencucian. Menurut Soemirat (2009), sulfida dihasilkan pada proses pewarnaan batik. Warna akan timbul jika ditambahkan natrium nitrit dan asam sulfat atau asam klorida. Zat warna yang digunakan pelarutannya dengan cara di reduksi dengan menggunakan sodium hydroxide $(\mathrm{NaOH})+$ sodium hydro sulfide (NaHS) menjadi larutan logam garam alkali. Konsentrasi sulfida pada seluruh stasiun pengamatan tidak memenuhi Baku Muku Kualitas Air Kelas II yang diijinkan berdasarkan Peraturan Pemerintah No. 82 tahun 2001 yaitu $0,002 \mathrm{mg} / \mathrm{l}$.

Hasil pengukuran Krom berkisar antara 0,10-0,16 mg/l. Peningkatan kadar krom pada Stasiun 3 mengindikasikan adanya akumulasi limbah cair yang berasal dari industri batik. Proses pengecapan industri batik akan menghasilkan limbah yang yang mengandung logam berat yaitu kromium. Walaupun kadar kromium $\mathrm{Cr}^{6+}$ yang terlarut air kecil, dalam $\mathrm{Cr}^{6+}$ memiliki daya racun paling tinggi apabila terakumulasi dalam tubuh manusia dan 
dapat menimbulkan kanker (Palar,1994). Apabila $\mathrm{Cr}^{6+}$ dikonsumsi oleh masyarakat dapat menimbulkan bahaya berbagai penyakit seperti kerusakan pada tulang hidung, di dalam paru-paru dapat menimbulkan kanker (Soemirat, 2009). Kadar $\mathrm{Cr}^{6+}$ mengalami peningkatan kembali pada Stasiun 6 disebabkan pada daerah tersebut terdapat penyamakan kulit. Senyawa kromium dalam limbah cair penyamakan kulit berasal dari proses penyamakan kulit, dimana Kromium sulfat $60-70 \%$ digunakan sebagai zat penyamak (Wahyuningtyas, 2001).

Kadar phenol berkisar antara 0,40 $0,53 \mathrm{mg} / \mathrm{l}$. Kadar phenol di seluruh stasiun penelitian berada diatas kadar maksimum Baku Mutu air kelas II. Senyawa phenol merupakan salah satu bahan kimia beracun yang dapat membahayakan bagi kesehatan manusia. Phenol yang terdapat dalam limbah cair batik berasal dari pelunturan lilin, pewarnaan dan pelorodan. Zat warna yang biasa digunakan oleh pengrajin Batik Trusmi adalah pewarna Naphtol, Indigosol dan Indanthrene.

Menurut Suhartono (1989), sebagian besar limbah sintesis zat warna textile, industri batu bara, kilang minyak, produksi plastik, sintesis kaprolaktam, sintesis resin, desinfektan, obat-obatan terdapat senyawa hidrokarbon aromatik yaitu phenol.

Hasil pengukuran kadar minyak dan lemak di seluruh stasiun didapatkan di atas batas maksimum baku mutu air kelas II berdasarkan PP 82 Tahun 2001 yaitu maksimum $1 \mathrm{mg} / \mathrm{l}$. Stasiun 2 dan Stasiun 3 sebagai stasiun yang terkena limbah batik tidak memiliki potensi besar terhadap kadar minyak dan lemak, karena semua stasiun memiliki kadar minyak dan lemak di atas baku mutu. Dari Tabel 3 diatas menunjukan bahwa kadar minyak dan lemak pada Stasiun 1 cukup tinggi dibandingkan dengan stasiun pengamatan yang lain karena merupakan daerah industri furniture dan banyak pabrik rotan. Proses pelapisan warna mebel maupun rotan menggunakan melamik dan plitur yang mengandung minyak cat dan minyak pewarna.

Kelimpahan makrobentos disajikan dalam Tabel 4. Kelimpahan individu pada seluruh stasiun pengamatan terdapat Chironomus sp. Menurut Trihadiningrum dan Tjondronegoro (1998), Chironomus $s p$ merupakan salah satu makrobentos indikator untuk perairan yang memiliki kualitas tercemar agak berat.44

Hasil pengukuran H'diperoleh 0-1,7077 (Tabel 4). Berdasarkan Indeks Keragaman Shannon Wiener untuk menentukan mutu kualitas perairan (Tabel 1), maka nilai $\mathrm{H}^{\prime}$ di Sungai Condong berada dalam katagori tercemar. Perubahan kualitas Sungai Condong oleh karenanya tidak hanya disebabkan oleh potensi limbah batik, namun limbah lainnya seperti limbah domestik, limbah rotan dan furniture, limbah pasar dan limbah pertanian.

Tabel 4.Kelimpahan (individu $/ \mathrm{m}^{2}$ ) makrobentos yang ditemukan di Sungai Condong

No Nama Spesies

Stasiun 1 Stasiun 2 Stasiun 3 Stasiun 4 Stasiun 5 Stasiun 6 Stasiun 7

\begin{tabular}{|c|c|c|c|c|c|c|c|c|}
\hline & Insecta & & & & & & & \\
\hline 1 & Branchiura sp. & 0 & 4 & 4 & 0 & 0 & 0 & 0 \\
\hline 2 & Chironomus sp. & 14 & 57 & 22 & 12 & 7 & 4 & 9 \\
\hline 3 & Culex sp. & 4 & 0 & 0 & 0 & 0 & 0 & 0 \\
\hline 4 & Cybister sp. & 7 & 0 & 0 & 0 & 0 & 0 & 0 \\
\hline 5 & Notonecta sp. & 2 & 0 & 0 & 0 & 0 & 0 & 0 \\
\hline 6 & Stenelmis sp. & 0 & 2 & 0 & 0 & 0 & 0 & 0 \\
\hline
\end{tabular}




\begin{tabular}{|c|c|c|c|c|c|c|c|c|}
\hline No & Nama Spesies & Stasiun 1 & Stasiun 2 & Stasiun 3 & Stasiun 4 & Stasiun 5 & Stasiun 6 & Stasiun 7 \\
\hline & Polycaeta & & & & & & & \\
\hline \multirow[t]{2}{*}{7} & Nereis sp. & 2 & 5 & 22 & 6 & 16 & 0 & 0 \\
\hline & Oligocaeta & & & & & & & \\
\hline \multirow[t]{2}{*}{8} & Lumbriculus sp. & 19 & 18 & 12 & 33 & 0 & 0 & 0 \\
\hline & Gastropoda & & & & & & & \\
\hline 9 & Brytinia truncatum & 0 & 1 & 0 & 1 & 0 & 0 & 0 \\
\hline 10 & Filopaludina martensis & 0 & 0 & 1 & 6 & 0 & 0 & 0 \\
\hline 11 & Melanoides tuberculata & 0 & 0 & 0 & 4 & 2 & 0 & 0 \\
\hline 12 & Physastra stagnalis & 0 & 0 & 1 & 0 & 0 & 0 & 0 \\
\hline 13 & Polypylis kennardi & 0 & 0 & 0 & 1 & 0 & 0 & 0 \\
\hline 14 & Sulcospira tertudinaria & 0 & 0 & 0 & 1 & 0 & 0 & 0 \\
\hline \multirow[t]{2}{*}{15} & Tarebia granifera & 0 & 0 & 4 & 3 & 0 & 0 & 0 \\
\hline & Crustacea & & & & & & & \\
\hline \multirow[t]{2}{*}{16} & Macrobrachium sp. & 0 & 0 & 5 & 0 & 0 & 0 & 0 \\
\hline & Malacostraca & & & & & & & \\
\hline \multirow[t]{4}{*}{17} & Parathelpusa sp. & 0 & 0 & 1 & 0 & 0 & 0 & 0 \\
\hline & Jumlah individu & 48 & 87 & 72 & 67 & 25 & 4 & 9 \\
\hline & Jumlah spesies & 6 & 6 & 9 & 9 & 3 & 1 & 1 \\
\hline & $\begin{array}{l}\text { Indeks Keanekaragaman } \\
\left(\mathrm{H}^{\prime}\right)\end{array}$ & 1.4789 & 1.0468 & 1.7077 & 1.5846 & 0.8441 & 0.00 & 0.00 \\
\hline
\end{tabular}

\section{Status Mutu Air Sungai Condong}

Hasil pengukuran parameter kualitas air Sungai Condong selanjutnya ditentukan status mutu airnya dengan menggunakan Metode STORET. Hasil perhitungan status mutu disajikan pada Tabel 5. Hasil perhitungan Metode Storet ketujuh stasiun penelitian memiliki nilai >-31. Berdasarkan kriteria status mutu air US-EPA, nilai >-31 artinya tercemar berat. Secara umum sumbangan pencemar yang menurunkan status mutu air di Sungai Condong adalah parameter TSS, DO, BOD, COD, sulfida, $\mathrm{Cr}^{6+}$, phenol, minyak dan lemak, serta makrobentos.

Tabel 5. Status mutu air Sungai Condong berdasarkan Metode Storet

\begin{tabular}{|c|c|c|c|c|c|c|c|c|c|c|}
\hline \multirow{2}{*}{ No } & \multirow{2}{*}{ Parameter } & \multirow{2}{*}{ Satuan } & \multirow{2}{*}{ BML Kls II } & \multicolumn{7}{|c|}{ Skor pada stasiun } \\
\hline & & & & 1 & 2 & 3 & 4 & 5 & 6 & 7 \\
\hline & Fisika & & & & & & & & & \\
\hline 1 & Suhu & ${ }^{\circ} \mathrm{C}$ & deviasi 3 & 0 & 0 & 0 & 0 & 0 & 0 & 0 \\
\hline 2 & TSS & $\mathrm{mg} / \mathrm{l}$ & 50 & -4 & -4 & -4 & -4 & 0 & -4 & -4 \\
\hline
\end{tabular}




\begin{tabular}{|c|c|c|c|c|c|c|c|c|c|c|}
\hline \multirow{2}{*}{ No } & \multirow{2}{*}{ Parameter } & \multirow{2}{*}{ Satuan } & \multirow{2}{*}{ BML Kls II } & \multicolumn{7}{|c|}{ Skor pada stasiun } \\
\hline & & & & 1 & 2 & 3 & 4 & 5 & 6 & 7 \\
\hline \multirow[t]{2}{*}{3} & Warna & TCU & $15^{*}$ & 0 & 0 & 0 & 0 & 0 & 0 & 0 \\
\hline & Kimia & & & & & & & & & \\
\hline 1 & $\mathrm{Ph}$ & - & $6-9$ & 0 & 0 & 0 & 0 & 0 & 0 & 0 \\
\hline 2 & DO & $\mathrm{mg} / \mathrm{l}$ & $>4$ & 0 & -2 & -2 & -8 & -10 & -8 & -10 \\
\hline 3 & $\mathrm{BOD}_{5}$ & $\mathrm{mg} / \mathrm{l}$ & 3 & -10 & -10 & -10 & -10 & -10 & -10 & -10 \\
\hline 4 & COD & $\mathrm{mg} / \mathrm{l}$ & 25 & -10 & -8 & -10 & -10 & -10 & -10 & -10 \\
\hline \multirow[t]{2}{*}{5} & Amoniak & $\mathrm{mg} / \mathrm{l}$ & Negatif & -10 & -10 & -10 & -10 & -10 & -10 & -10 \\
\hline & sebagai N & & & & & & & & & \\
\hline 6 & Sulfida & $\mathrm{mg} / \mathrm{l}$ & 0,002 & -10 & -10 & -10 & -10 & -10 & -10 & -10 \\
\hline 7 & $\mathrm{Cr}(\mathrm{VI})$ & $\mathrm{mg} / \mathrm{l}$ & 0,05 & -10 & -10 & -10 & -10 & -10 & -10 & -10 \\
\hline 8 & Phenol & $\mathrm{mg} / \mathrm{l}$ & 0,001 & -10 & -10 & -10 & -10 & -10 & -10 & -10 \\
\hline 9 & Minyak & $\mathrm{mg} / \mathrm{l}$ & 1 & -10 & -10 & -10 & -10 & -10 & -10 & -10 \\
\hline
\end{tabular}

Biologi

$1 H^{\prime}$ Makrobentos

$\mathrm{m}^{2} \quad 3^{* *}$

$-15$

$\begin{array}{llllll}-15 & -15 & -15 & -15 & -9 & -9\end{array}$

$-89$

$-89$

$-91$

$\begin{array}{llll}-97 & -95 & -91 & -93\end{array}$

Satus Mutu

TB TB TB TB TB TB TB

Keterangan : TB = Tercemar berat; BML KLS II = Baku Mutu Air Kelas II;

${ }^{*}=$ Persyaratan warna perairan menurut Permenkes RI No 416 Tahun 1990

${ }^{* *}=$ Persyaratan mutu kualitas perairan berdasarkan Index Shannon Wiener (Wilhm \& Dorris dalam Dahuri et al., 1995 )

\section{Simpulan}

Berdasarkan uraian pada hasil dan pembahasan, maka baik sebelum maupun setelah terkena buangan limbah cair batik berada pada kondisi yang tidak memenuhi Baku Mutu untuk irigasi pertanian, pembudidayaan ikan air tawar dan prasarana/sarana rekreasi air. Status mutu Sungai Condong sebelum dan sesudah limbah batik termasuk tercemar berat.

\section{Daftar Pustaka}

Ali, A., Soemarno, dan Purnomo, M. 2013. Kajian kualitas air dan status mutu air sungai metro di Kecamatan Sukun
Kota Malang. Jurnal Bumi Lestari 13(2): 265-274 Anonim.2010. www/pewarna/bahan_pewarna.htm. Diakses pada tanggal 5 Juli 2015.

Astirin, O. P dan Winarno, K. 2000. Peran pseudomonas dan khamir dalam perbaikan kualitas dan decolorasi limbah cair industri batik tradisional. Bio Smart 2 (1), 13-19

Casta dan Taruna. 1997. Batik Cirebon. Badan Komunikasi, Kebudayaan dan Pariwisata Kabupaten Cirebon, Cirebon

Dahuri, R. 1995. Metode dan Pengukuran Kualitas Air Aspek Biologi. IPB, Bogor

Darmono.2001. Lingkungan Hidup dan Pencemaran (Hubungannya dengan 
Toksikologi Senyawa Logam). Universitas Indonesia Press, Jakarta

Dinas Pengelolaan Sumber Daya Air dan Pertambangan (PSDAP) Kabupaten Cirebon. 2014. Profil Sungai Condong. Dinas Pengelolaan Sumber Daya Air dan Pertambangan, Cirebon

Effendi, H. 2003. Telaah Kualitas Air Bagi Pengelolaan Sumber Daya dan Lingkungan Perairan. Kanisus, Yogyakarta

Kementrian Lingkungan Hidup (KLH). 2004. Laporan Status Lingkungan Hidup Indonesia 2003. Kementerian Lingkungan Hidup, Jakarta.

Odum, E. P. 1993. Dasar-dasar Ekologi. Gadjah Mada University Press, Yogyakarta

Palar. 1994. Pencemaran dan Toksikologi Logam Berat. Rineka Cipta, Jakarta

Presiden Republik Indonesia. 2001. Peraturan Pemerintah Republik Indonesia Nomor 82 tahun 2001 tentang Pengelolaan KualitasAir dan Pengendalian Pencemaran Air. Deputi Sekretariat Kabinet, Jakarta

Ramesh, B., Parande A, K., Raghu, S., and Kumar, T. 2007. Cotton textile processing:waste generation and effluent treatment. Journal of cotton science 11:141-153
Sawyer, C.N., and P.L. McCarty. 1978. Chemistry for Sanitary Engineers. 3th Ed. McGrow-Hill Book Company, Tokyo.

Soemirat, J. 2009. Kesehatan Lingkungan. Gajah Mada University Press, Yogyakarta

Suhartono, M.T. 1989. Enzim dan Bioteknologi. PAU Bioteknologi IPB, Bogor

Suripin.2004. Pelestarian Sumber Daya Tanah dan Air. Andi, Yogyakarta

Toroz. 2007. Pollutants of textile industry wastewater and assessment of its discharge limits by water quality standard. Turkish journal of fisheries and aquatic sciences 7: 97-103

Trihadiningrum, Y., dan Tjondronegoro, I. 1998. Makroinvertebrata sebagai Indikator Pencemaran Badan Air Tawar di Indonesia.Jakarta: Lingkungan dan Pembangunan 18 (1): 45-60

Wahyuningtyas, N,.2001. Pengolahan Limbah Cair Khromium dari Proses Penyamakan Kulit Menggunakan Senyawa Alkali Natrium Karbonat (Na2CO3). Sekolah Tinggi Teknik lingkungan, Yogyakarta 